\title{
PROFIL MEDIA GABIDROID PADA PEMBELAJARAN BILANGAN DI SEKOLAH DASAR
}

\author{
Febrian Murti Dewanto \\ Husni Wakhyudin \\ Mudzanatun \\ Universitas PGRI Semarang \\ Jalan Sidodadi Timur No. 24 Dr. Cipto Semarang \\ email : febrianmd@upgris.ac.id
}

\begin{abstract}
The purpose of this study is to produce gabidroid media for the learning of numbers at primary schools. In this research, the development of media using research and development approach. The research data retrieval by means of observation, questionnaires and interviews. Data validity is done by means of triangulation of sources. Based on the results, the data analysis obtained 3.25 on very well criteria, the results of media legibility trials obtained 3.67 on very well criteria. The gabidroid media is worth to use because it satisfies common aspects, content feasibility, media presentation, language feasibility, and graphic eligibility.
\end{abstract}

Keywords: gabidroid media, development, number learning.

\begin{abstract}
Abstrak: Tujuan penelitian ini adalah untuk menghasilkan media gabidroid pada pembelajaran bilangan di sekolah dasar. Pengembangan media pembelajaran dalam penelitian ini menggunakan pendekatan penelitian dan pengembangan. Teknik pengambilan data penelitian dengan cara observasi, angket dan wawancara, keabsahan data dilakukan dengan cara triangulasi sumber. Berdasarkan hasil analisis data diperoleh validasi ahli 3,25 kriteria baik sekali, hasil uji coba keterbacaan media diperoleh 3,67 kriteria baik sekali. Media gabidroid layak digunakan karena memenuhi aspek umum, kelayakan isi, penyajian media, kelayakan bahasa, dan kelayakan grafik.
\end{abstract}

Kata kunci: media gabidroid, pengembangan, pembelajaran bilangan.

Penelitian dan pengembangaan ini dilaksanakan berdasarkan hasil analisis kebutuhan yang dilakukan di sekolah dasar di kota Semarang. Berdasarkan data yang diperoleh dari 43 responden guru di sekolah dasar melalui kuisioner tentang profil urgensi operasi hitung pada pembelajaran, pemanfaatan sumber belajar, strategi pembelajaran materi operasi hitung, ketersediaan media pembelajaran dan komponen media pembelajaran. Berdasarkan analisis data hasil observasi di sekolah dasar diperoleh profil urgensi operasi hitung pada bilangan bulat yakni dari 43 responden, dapat dilihat sebanyak 36 $(83,72 \%)$ responden menyatakan bahwa materi operasi hitung pada bilangan bulat sangat perlu diajarkan di sekolah dasar, dan sebanyak 7 (16,27\%) responden menyatakan perlu, hal ini menunjukkan bahwa materi operasi hitung bilangan dibutuhkan di sekolah dan sebaiknya diajarkan dengan baik dengan pemanfaatan media pembelajaran untuk mengenalkan konsep operasi hitung bilangan bulat.

Sedangkan untuk pemanfaatan buku matematika sebagai sumber belajar yang dapat memotivasi siswa dari 43 responden dapat ditunjukkan sebanyak $32,55 \%$ responden menyatakan bahwa buku matematika yang ada belum dapat memotivasi siswa dalam pembelajaran dan $67,44 \%$ responden 
menyatakan bahwa buku matematika yang ada sudah dapat memotivasi siswa dalam mempelajari materi operasi hitung pada bilangan bulat. Dengan demikian, hal ini memberikan kesempatan bahwa masih bisa dilakukan pengembangan dalam pemanfaatan media dalam pembelajaran operahi hitung pada bilangan bulat.

Dalam hal strategi penyampaian materi pada operasi hitung dari 43 responden terdapat 30,23\% responden menyatakan menginginkan strategi pembelajaran yang singkat dan jelas, 48,83\% res-ponden menginginkan pembelajaran operasi hitung pada bilangan bulat diuraikan, dan $20.93 \%$ res-ponden memberikan jawaban lain. Responden lain menyatakan secara garis besar responden menginginkan bahwa dalam pembelajaran operasi hitung hendaknya didukung dengan pemanfaatan media yang konkrit atau alat peraga yang dapat divisualisasikan baik dalam bentuk media yang bisa dimanupilasi maupun dibuat permainan.

Selanjutnya, untuk ketersediaan media pembelajaran pada pembelajaran operasi hitung bilangan bulat ditunjukkan dari 43 responden, sebanyak 37\% responden menyatakan bahwa ketersediaan media yang ada sudah memadai, 48,83\% responden menyatakan bahwa ketersediaan media yang ada kurang memadai, dan 9,3\% responden menyatakan bahwa ketersediaan media tidak memadai, hal ini masih memungkinkan dilakukan pengembangan media pembelajaran yang membantu pembelajaran pada materi operasi hitung pada bulangan bulat.

Selain itu, dalam perkembangannya media pembelajaran yang akan dikembangkan harus memuat materi, contoh soal, simulasi, latihan, dan video, data tentang kebutuhan komponen pengembangan media didapatkan data yakni, dalam pengembangan media pembelajaran responden mengharapkan media yang dikembangkan memuat kajian materi, simulasi, contoh soal-jawaban, latihan, dan tes formatif. Sedangkan 13,95\% responden memiliki jawaban lain yaitu materi, contoh soal, simulasi, latihan, audio visual dan evaluasi. Perkembangan teknologi informasi dan komunikasi yang dapat digunakan sebagai media pembelajaran saat ini menuntun guru berinovasi menciptakan media pembelajaran yang menarik dan praktis, salah satunya yaitu melalui Android. Android merupakan sistem operasi berbasis Linux, yang termasuk ke dalam sistem operasi open source yang dirancang untuk perangkat seluler layar sentuh misalnya smartphone dan tablet.

Dari hasil riset secara umum diperkirakan sekira 55 juta pengguna smartphone di Indonesia, sedangkan total penetrasi pertumbuhannya mencapai $37,1 \%$. Jutaan anak usia sekolah dasar kecanduan gadget terutama dalam bentuk tablet (Novita \& Khotimah, 2016). Tanpa harus diajarkan, siswa dapat mengoperasikannya secara otodidak. Hal itu memberikan kesempatan yang besar bagi para guru untuk membuat aplikasi media pembelajaran berbasis Android. Beberapa hasil penelitian yang dikemukakan oleh Orey, Jones, \& Branch (2010) menunjukkan dampak positif dari penggunaan media sebagai bagian integral pembelajaran di kelas, atau sebagai cara utama pembelajaran langsung, salah satunya adalah kualitas hasil belajar dapat ditingkatkan bila integrasi kata dan gambar sebagai media pembelajaran dapat mengkomunikasikan elemen-elemen pengetahuan dengan cara yang terorganisasi dengan baik, spesifik dan jelas.

Dari uraian di atas, dapat disimpulkan peranan atau manfaat praktis dari penggunaan media pembelajaran di dalam proses belajar mengajar, yaitu media pembelajaran dapat meningkatkan dan mengarahkan perhatian anak, sehingga dapat menimbulkan motivasi belajar, interaksi yang lebih langsung antara siswa dan lingkungannya, dan kemungkinan siswa untuk belajar sendiri sesuai dengan kemampuan dan minatnya. Berdasarkan paparan studi pendahuluan dan studi literatur diatas maka untuk meningkatkan kemampuan operasi hitung bilangan bulat siswa sekolah dasar maka tujuan penelitian ini mengembangkan media GABIDROID (Garis Bilangan Berbasis Android). Media GABIDROID adalah aplikasi berbasis android yang menjabarkan mengenai penggunaan garis bilangan dalam memahami konsep operasi hitung bilangan bulat. Media GABIDROID dapat menciptakan ketertarikan siswa dalam memahami operasi hitung bilangan bulat, dikarenakan kemudahan dalam penggunaannya dan dapat diakses diberbagai tempat.

\section{METODE}

Penelitian ini merupakan jenis penelitian $R e$ search and Development (R\&D). Prosedur pengembangan media pembelajaran menggunakan model Borg dan Gall (2003) yang meliputi 10 tahapan. Penelitian ini sudah menyelesaikan tahapan pada 
tahun pertama dari rencana 2 tahun. Pada tahun pertama telah dilaksanakan 5 langkah penelitian awal, yaitu (1) penelitian awal dan pengumpulan informasi, meliputi pengumpulan data awal termasuk literatur, observasi kelas, identifikasi permasalahan, dan merangkum permasalahan; (2) perencanaan, yaitu merumuskan tujuan kompetensi pembuatan produk media, merancang sampel-sampel penelitian, dan membuat naskah desain media GABIDROID, serta membuat akun developer pada Google; (3) pengembangan produk awal, yaitu dengan mendesain dan membuat produk media gabidroid, dihasilkan Prototype I; (4) uji coba produk awal, dengan cara uji ahli Prototype I pada 2 orang pakar ahli media melalui lembar validasi produk; dan (5) revisi produk utama, yaitu dihasilkan media Gabidroid yang dinilai baik oleh 2 orang pakar kemudian didaftarkan dalam Playstore.

Pada tahun kedua akan dilaksanakan 5 langkah penelitian selanjutnya, yaitu (1) uji coba produk utama, yaitu menguji lapangan lebih luas Media Gabidroid dengan mengambil sampel siswa salah satu SD di Kota Semarang; (2) revisi produk operasional, yaitu revisi tahap 2 desain produk media GABIDROID dihasilkan Prototype II; (3) uji coba produk operasional, uji kelayakan Prototype II dengan mengambil sampel beberapa di SD Kota Semarang; (4) Implementasi media GABIDROID; dan (5) diseminasi dan sosialisasi melalui seminar nasional atau jurnal ilmiah.

Instrumen Lembar validasi Media Gabidroid digunakan untuk memperoleh masukan, saran dan kritik dari pakar ahli media. Lembar validasi beserta media gabidroid diberikan kepada para validator, kemudian validator memberikan penilaian terhadap media gabidroid dengan mengisi lembar validasi sesuai dengan petunjuk yang diberikan atau menuliskan butir-butir revisi langsung pada naskah. Media gabidroid yang sudah di validasi ahli, selanjutnya dianalisis secara deskriptif kualitatif. Hasil validasi berupa penilaian umum yang meliputi: baik sekali, baik, kurang, dan kurang sekali. Selanjutnya media yang dikembangkan dapat digunakan tanpa revisi, dapat digunakan dengan sedikit revisi, dapat digunakan dengan banyak revisi, atau tidak dapat digunakan dan masih memerlukan konsultasi dan pembenahan ulang. Kualitas media yang dikembangkan dikatakan baik jika jumlah data hasil validasi oleh validator terletak pada interval kategori baik atau baik sekali.

\section{HASIL}

\section{Profil Media Gabidroid}

Media Gabidroid diproduksi menggunakan software pengembangan perangkat lunak dan aplikasi berbasis vector dan animasi yaitu Adobe Flash 5.5 dan Adobe AIR. Pada tabel dibawah ini adalah desain user interface Media Gabidroid yang sudah dikembangkan hingga versi 2.7.

\section{Tabel 1. Desain Halaman Utama Media} Gabidroid

\begin{tabular}{|c|c|}
\hline Tampilan & Komponen \\
\hline 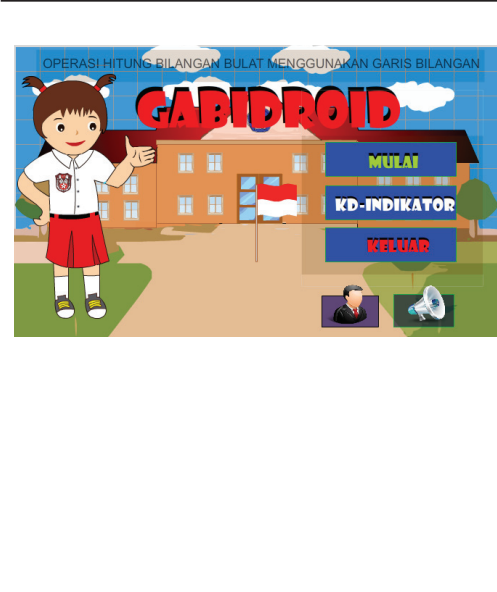 & $\begin{array}{l}\text { Scene :Utama } \\
\text { Gambar: } \\
\text { 1.Background } \\
\text { 2. Gabi } \\
\text { Tombol : } \\
\text { 3. Mulai } \\
\text { 4. KD-Indikator } \\
\text { 5. Keluar } \\
\text { 6.Icon Profil } \\
\text { 7.Icon Sound } \\
\text { Audio: } \\
\text { Free opening. } \\
\text { mp3 }\end{array}$ \\
\hline
\end{tabular}

Keterangan tabel 1 yakni halaman utama diproduksi dalam scene utama setelah halaman opening, terdiri dari tombol Mulai untuk menuju Scene Menu, tombol KD-Indikator untuk menuju scene keterangan Kompetensi Dasar dan Indikator, tombol Keluar untuk keluar dari media, diikuti icon profil pengembang dan icon suara untuk mengaktifkan dan menonaktifkan musik latar.

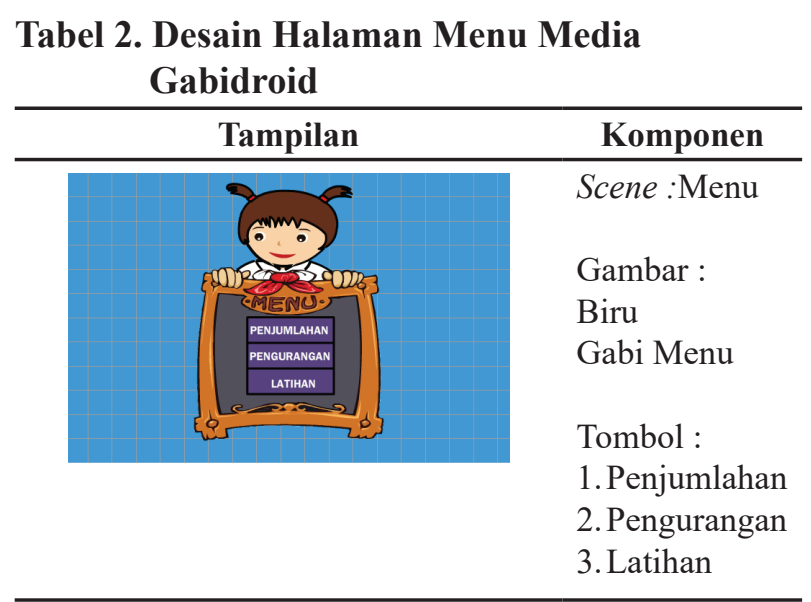


Keterangan tabel 2 yakni halaman Menu diproduksi dalam scene menu yang muncul ketika tombol mulai di halaman utama di-klik, terdiri dari tombol Penjumlahan untuk menuju scene Penjumlahan, tombol Pengurangan menuju scene pengurangan, tombol Latihan untuk menuju scene latihan yang berisi soal interaktif penjumlahan dan pengurangan.

\section{Tabel 3. Desain Halaman Penjumlahan}

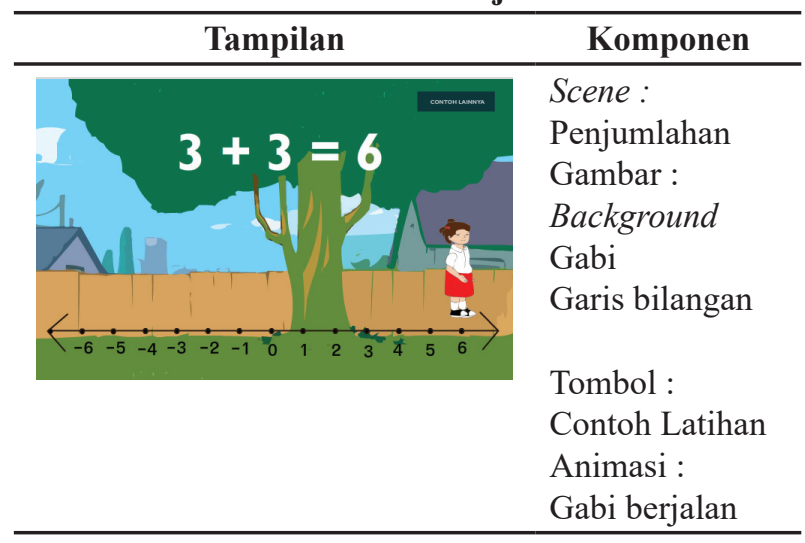

Keterangan tabel 3 yakni halaman Penjumlahan diproduksi dalam scene penjumlahan yang muncul ketika tombol penjumlahan di halaman menu di-klik, terdiri dari tombol Contoh latihan untuk menuju scene latihan penjumlahan. Pada halaman ini terdapat animasi Gabi yang bergerak ke kanan untuk bilangan bulat positif sehingga hasil penjumlahan adalah bilangan dimana Gabi berhenti. Pada tahapan ini setelah mendesain dan mengembangkan produk media Gabidroid, dihasilkan Prototype yang terdiri dari 20 scene.

\section{Uji Coba Produk}

\section{Validasi Desain}

Uji coba produk awal dengan cara uji ahli Prototype I oleh ahli media melalui lembar validasi produk . Uji ahli media ini dilakukan oleh Ir. Agung Handayanto, M.Kom (UPGRIS) ahli media dengan background pendidikan matematika dan komputer dan Firman Daru, S.Kom, M.Kom (Universitas Semarang) ahli media pembelajaran dengan spesialisasi Flash.

Media GABIDROID yang sudah di validasi ahli, selanjutnya dianalisis secara deskriptif/kualitatif. Hasil validasi berupa penilaian umum yang meliputi: Baik sekali, baik, kurang, dan kurang sekali. Selanjutnya media yang dikembangkan da- pat digunakan tanpa revisi, dapat digunakan dengan sedikit revisi, dapat digunakan dengan banyak revisi, atau tidak dapat digunakan dan masih memerlukan konsultasi dan pembenahan ulang. Kualitas media yang dikembangkan dikatakan baik jika jumlah data hasil validasi oleh validator terletak pada interval kategori baik atau baik sekali.

Dapat di lihat pada tabel 4 hasil analisis uji validasi ahli menunjukan pada penilaian rata-rata $=3,25$, maka media dalam kriteria baik sekali. Meskipun demikian media gabidroid mendapatkan masukan (revisi) pada respon saat siswa menjawab dengan tepat diharapkan diberikan tambahan applause pada program atau reward. Sedangkan saat jawaban salah ditambahkan ungkapan-ungkapan yang memotivasi siswa.

\section{Hasil Uji Coba}

Dari tabel 5 didapatkan hasil analisis uji coba dilapangan menunjukan $\mathrm{x}=3,67$, maka media dalam kriteria baik sekali. Namun masih ada beberapa catatan dari validator, antara lain disarankan menambah sistem skoring otomatis dan peletakan tombol. Dengan demikian media gabidroid layak untuk digunakan dalam pembelajaran bilangan di sekolah dasar karena memenuhi kriteria baik sekali mencakup aspek umum, aspek kelayakan isi, aspek penyajian media, dan aspek kelayakan grafik.

\section{PEMBAHASAN}

Pada penelitian ini telah dikembangkan media Gabidroid berbasis IT yang menggunakan software android. Android adalah sebuah sistem operasi untuk perangkat mobile berbasis linux yang mencakup sistem operasi dan aplikasi. Android menyediakan platform terbuka bagi para pengembangan untuk menciptakan aplikasi. Awalnya, Google.inc (www. google.com) membeli Android Inc (www.android. com) yang merupakan pendatang baru yang membuat perangkat lunak untuk telepon selular (ponsel) atau smartphone. Untuk mengembangkan Android, dibentuklah Open Handset Alliance (OHA), sebuah perusahaan konsorsium dari 34 perusahaan peranti lunak (software), peranti keras (hardware) dan telekomunikasi seperti google inc., HTC, Intel, motorolla, Qualcomm, T-mobile dan Nvidia. Saat ini terdapat 2 (dua) jenis distributor sistem operasi android (Wang, Duan, Ma, \& Wang, 2012). Pertama yang mendapat dukungan penuh dari Google atau 
Tabel 4. Hasil Uji Validasi Ahli

\begin{tabular}{lcccccc}
\hline & $\begin{array}{c}\text { Skor Aspek } \\
\text { Umum }\end{array}$ & $\begin{array}{c}\text { Skor Aspek } \\
\text { Kelayakan Isi }\end{array}$ & $\begin{array}{c}\text { Skor Aspek } \\
\text { Penyajian } \\
\text { Media }\end{array}$ & $\begin{array}{c}\text { Skor Aspek } \\
\text { Kelayakan } \\
\text { Bahasa }\end{array}$ & $\begin{array}{c}\text { Skor Aspek } \\
\text { Kelayakan } \\
\text { Kegrafikan }\end{array}$ & Total \\
\hline $\begin{array}{l}\text { S Soal } \\
\text { Skor maksi- }\end{array}$ & 6 & 4 & 7 & 2 & 5 & 24 \\
mal & 24 & 16 & 28 & 8 & 20 & 96 \\
Skor (s1) & 20 & 13 & 24 & 6 & 15 & 78 \\
$\mathbf{x}$ & $\mathbf{3 , 3 3}$ & $\mathbf{3 , 2 5}$ & $\mathbf{3 , 4 3}$ & $\mathbf{3}$ & $\mathbf{3}$ & $\mathbf{3 , 2 5}$ \\
\hline
\end{tabular}

Tabel 5. Hasil Uji Keterbacaan media di sekolah

\begin{tabular}{lcccccc}
\hline & $\begin{array}{c}\text { Skor Aspek } \\
\text { Umum }\end{array}$ & $\begin{array}{c}\text { Skor Aspek } \\
\text { Kelayakan Isi }\end{array}$ & $\begin{array}{c}\text { Skor Aspek } \\
\text { Penyajian } \\
\text { Media }\end{array}$ & $\begin{array}{c}\text { Skor Aspek } \\
\text { Kelayakan } \\
\text { Bahasa }\end{array}$ & $\begin{array}{c}\text { Skor Aspek } \\
\text { Kelayakan } \\
\text { Kegrafikan }\end{array}$ & Total \\
\hline $\begin{array}{l}\text { S Soal } \\
\text { Skor maksi- }\end{array}$ & 6 & 4 & 7 & 2 & 5 & 24 \\
mal & 24 & 16 & 28 & 8 & 20 & 96 \\
Skor (s2) & 21 & 15 & 25 & 8 & 19 & 88 \\
$\mathbf{x}$ & $\mathbf{3 , 5}$ & $\mathbf{3 , 7 5}$ & $\mathbf{3 , 5 7}$ & $\mathbf{4}$ & $\mathbf{3 , 8}$ & $\mathbf{3 , 6 7}$ \\
\hline
\end{tabular}

Google Mail Service (GMS) dan kedua adalah yang benar-benar bebas distribusinya tanpa dukungan langsung google dikenal sebagai Open Handset Distribution (OHD).

Sistem operasi Android merupakan sistem operasi yang multitasking yang memiliki cara kerja berbeda dengan sistem operasi lainnya. Android bekerja dengan metodologi tidak mematikan aplikasi yang sedang berjalan. Android memang didesain meninggalkan fungsi menutup/mematikan aplikasi. Para perancang Android menilai hal ini dinilai tidak efisien, atas dasar pengguna ponsel akan menggunakan dan berinteraksi dengan berbagai macam aplikasi sepanjang hari. Saat aplikasi ditinggalkan, aplikasi juga diizinkan untuk menjaga agar proses yang berjalan di background (true multitasking) yang memungkinkan untuk melanjutkan melakukan pekerjaan apapun yang perlu dilakukan. Ketika tidak ada memori RAM yang tersisa Android akan mulai menutup aplikasi yang dianggap memiliki prioritas rendah dengan mendeteksi aplikasi yang jarang digunakan pada saat itu dan dianggap tidak penting.

Untuk menjalakan suatu aplikasi pada sistem operasi Android dapat dilakukan dengan cara menginstal secara manual atau secara otomatis melalui Playstore. Playstore merupakan market terbesar untuk mengunduh aplikasi untuk sistem operasi Android. Pada Playstore terdapat berbagai macam aplikasi yang disediakan mulai dari buku, aplikasi dan juga games yang bisa didapatkan secara gratis maupun berbayar. Sistem operasi open source yaitu sebuah sistem operasi dengan sumber terbuka yang memungkinkan dapat dikembangkan secara terbuka. Saat ini perangkat seluler layar sentuh seperti smartphone dan tablet sudah tidak asing lagi bagi siswa sekolah dasar. Pengembangan media ini pada tahap orientasi pembelajaran membantu efektivitas proses pembelajaran dan penyampaian pesan atau materi pelajaran pada siswa (Fajrin, 2015). Di samping itu media pembelajaran juga dapat membantu siswa meningkatkan pemahaman, menyajikan data dengan menarik dan terpercaya, memudahkan penafsiran data, memadatkan informasi, serta membangkitkan motivasi dan minat siswa dalam belajar (Kustandi, 2011:21).

Adapun peranan media dalam pembelajaran menurut Miarso (2004:458) diantaranya, memberikan rangsangan yang bervariasi kepada otak kita, sehingga dapat berfungsi secara optimal, mengatasi keterbatasan pengalaman yang dimiliki oleh para mahasiswa atau peserta didik, media dapat melampaui batas ruang kelas, karena banyak hal yang tak mungkin untuk dialami secara langsung di dalam kelas oleh siswa, memungkinkan adanya interaksi langsung antara mahasiswa dan lingkungannya, memiliki keseragaman pengamatan, membangkitkan keinginan dan minat baru, membangkitkan mo- 
tivasi dan merangsang untuk belajar, memberikan pengalaman yang integral/menyeluruh dari sesuatu yang konkret maupun abstrak, memberikan kesempatan kepada siswa untuk belajar mandiri. Purbasari, Kahfi, \& Mahmudin (2013:2) menyatakan bahwa media berbasis android selain memiliki keunggulan juga memiliki kelemahan. Adapun kelemahan media pembelajaran yang dikembangkan antara lain tidak dapat dioperasikan pada perangkat mobile dengan sistem operasi selain Android, animasi bangun tiga dimensi belum dalam animasi $3 \mathrm{D}$, dan interaktivitas media masih kurang.

Hasil analisis uji validasi ahli menunjukan bahwa media Gabidroid mencapai baik sekali. Revisi dilakukan dengan menambahkan reward berupa applause pada program. Sedangkan hasil analisis uji coba dilapangan menunjukan $\mathrm{x}=3,67$ sehingga media mencapai kriteria baik sekali. Revisi dilakukan dengan menambah sistem skoring otomatis dan peletakan tombol. Tercapainya kriteria valid media Gabidroid yang dikembangkan menurut Shorkey \& Uebel (2014) menjelaskan bahwa media pembelajaran dapat memenuhi tiga fungsi utama apabila media itu digunakan untuk perorangan, kelompok, atau kelompok yang besar jumlahnya. Pertama, media hendaknya memotivasi minat dan tindakan, dimana media pembelajaran dapat direalisasikan dengan teknik drama atau hiburan. Kedua, menyajikan informasi, media pembelajaran dapat digunakan dalam rangka penyajian informasi di hadapan sekelompok siswa. Ketiga, isi dan bentuk penyajian bersifat sangat umum, berfungsi sebagai pengantar, ringkasan dan laporan atau pengetahuan latar belakang, dan memberi instruksi.

Pada pembelajaran ICT yang telah dilaksanakan memberikan dampak yang baik yaitu dapat menuntaskan hasil belajar peserta didik dan menumbuhkan keaktifan peserta didik (Tsatalsa, 2016). Sehubungan dengan pemanfaatan teknologi dalam dunia pendidikan, yang menjadi trendsaat ini adalah menggunakan berbagai media (multimedia), yaitu kombinasi berbagai media audio, visual, grafis dan lain sebagainya yang diarahkan kepada komputer yang dalam perkembangannya sangat pesat dan sangat membantu dalam dunia pendidikan. Multimedia memiliki beberapa kelebihan yaitu memberikan kemudahan bagi siswa untuk belajar secara individual maupun secara kelompok. Selain itu, menurut Dwi (2014) media juga memberikan kemudahan bagi guru dalam menyampaikan materi, media komputer (multimedia interaktif) juga memberikan rangsangan yang cukup besar dalam meningkatkan motovasi belajar siswa.

\section{SIMPULAN DAN SARAN}

\section{Simpulan}

Penelitian pada tahun pertama ini sudah dilakukan kelima tahapan awal dan diperoleh hasil sebagai berikut. Pertama, hasil analisis pendahuluan penelitian ini adalah materi operasi hitung pada bilangan bulat sangat perlu diajarkan kepada siswa sekolah dasar untuk meningkatkan keterampilan berhitung siswa, ketersediaan media pembelajaran di sekolah dasar pada kelas 4 (empat) pada pembelajaran materi operasi hitung pada bilangan bulat masih perlu dikembangkan, komponen yang harus ada pada pengembangan media diantaranya konten materi, simulasi, contoh soal, latihan, tes, video dan evaluasi. Kedua, perancangan aplikasi/ media Gabidroid menggunakan kaidah storyboard berbasis multimedia interaktif. Ketiga, desain dan pengembangan produk Media Gabidroid dengan software Adobe Flash dan AIR sudah berjalan dengan baik. Keempat, hasil validasi ahli dan keterbacaan media dinyatakan layak untuk digunakan dalam pembelajaran bilangan di sekolah dasar karena memenuhi kriteria baik sekali Hasil uji validasi ahli adalah 3,25 dan 3,67 (baik sekali)

\section{Saran}

Penelitian ini akan dilanjutkan pada tahun kedua untuk menguji keefektifan media Gabidroid pada pembelajaran bilangan untuk meningkatkan kemampuan operasi hitung di Sekolah Dasar dengan cara diujicobakan secara luas.

\section{DAFTAR PUSTAKA}

Dwi, A. 2014. Pengembangan Media Interaktif Dilat Pedang Untuk Pembelajaran Seni Tari Pada Siswa Sekolah Dasar. Sekolah Dasar: Kajian Teori dan Praktik, 23(2).

Fajrin, O.R. 2015. Hubungan Tingkat Penggunaan Teknologi Mobile Gadget Dan Eksistensi Permainan Tradisional Pada Anak Sekolah Dasar. Jurnal Mahasiswa Sosiologi, 2(6).

Gall, M., \& Walter, B. 2003. Education Research. New York: Allyn and Bacon.

Hamalik, O. 2004. Proses Belajar Mengajar. Jakarta : Bumi Aksara. 
Kustandi, S. 2011. Media Pembelajaran Manual dan Digital. Bogor: Galia Press.

Miarso, Y.H. 2004. Media dalam Proses Belajar Mengajar. Jakarta: Prenada Media.

Novita, S., \& Khotimah, N. 2016. Dampak Penggunaan Gadget Terhadap Interksi Sosial Anak Usia 5-6 Tahun. Jurnal PAUD Teratai UNESA, 5(3).

Orey, M., Jones, S.A., \& Branch, R.M. 2010. Educational Media and Technology Year Book Volume 35. New York : Springer ScienceBusiness Media.

Purbasari, J.R., Kahfi, M.S., \& Mahmudi, Y. 2013. Pengembangan Aplikasi Android Sebagai Media Pembelajaran Matematika Pada Materi Dimensi Tigas Untuk Siswa. Jurnal Online Universitas Negeri Malang, 1(1).
Shorkey, C.T., \& Uebel, M. 2014. History and Development of Instructional Technology and Media in Social Work Education. Journal of Social Network, 50 (2).

Tsatalsa,A.N. 2016.PengembanganBahanAjarMata Kuliah Pengembangan Media Pembelajaran Macro Media Flash Professional 8. Jurnal Matematika \& Pendidikan Matematika, 3(1).

Wang, C., Duan, W., Ma, J., \& Wang., C. 2012. The Research Of Android System Architecture And Application Programming. Artikel disajikan pada Proceedings of 2011 International Confeerence On Computer Science and Network Technology, Harbin, China. 